\title{
Corrigendum to "Denaturation Kinetics of Whey Protein Isolate Solutions and Fouling Mass Distribution in a Plate Heat Exchanger"
}

\author{
Marwa Khaldi, ${ }^{1,2,3}$ Gilles Ronse, ${ }^{1,2}$ Christophe André,, ${ }^{1,2,4}$ Pascal Blanpain-Avet, ${ }^{1,2}$ \\ Laurent Bouvier, ${ }^{1,2}$ Thierry Six, ${ }^{1,2}$ Saloua Bornaz, ${ }^{5}$ Thomas Croguennec, ${ }^{6}$ \\ Romain Jeantet, ${ }^{6}$ and Guillaume Delaplace ${ }^{1,2}$
}

${ }^{1}$ INRA, UR638, Processus aux Interfaces et Hygiène des Matériaux (PIHM), BP 20039, 369 rue Jules Guesde, 59651 Villeneuve d'Ascq, France

${ }^{2}$ Unité de Matériaux et Transformations (UMET), UMR CNRS 8207, Université de Lille 1, 59650 Villeneuve d'Ascq, France

${ }^{3}$ Institut National Agronomique de Tunisie, 43 avenue Charles Nicolle, 1082 Tunis Mahrajène, Tunisia ${ }^{4}$ HEI, Laboratoire de Génie des Procédés, 59046 Lille, France

${ }^{5}$ Ecole Supérieure des Industries Alimentaires de Tunis, 58 avenue Alain Savary, 1003 Tunis El Khadra, Tunisia

${ }^{6}$ INRA, AGROCAMPUS OUEST, UMR 1253, 35042 Rennes, France

Correspondence should be addressed to Marwa Khaldi; marwa.khaldi@lille.inra.fr

Received 2 December 2015; Accepted 30 December 2015

Copyright (C) 2016 Marwa Khaldi et al. This is an open access article distributed under the Creative Commons Attribution License, which permits unrestricted use, distribution, and reproduction in any medium, provided the original work is properly cited.

In the paper titled "Denaturation Kinetics of Whey Protein Isolate Solutions and Fouling Mass Distribution in a Plate Heat Exchanger" [1], the authors found 2 errors:

(i) Due to a data export error, 2 values were inversed in Table 3: at $120 \mathrm{ppm}$ total calcium, the value of $E_{A \text {,unf }}$ $=271.2 \mathrm{~kJ} \cdot \mathrm{mol}^{-1}$ mentioned in the published paper was replaced by the correct $E_{A \text {,unf }}=360.7 \mathrm{k} \cdot \mathrm{mol}^{-1}$, and at $100 \mathrm{ppm}$ total calcium, the value of $E_{A, \mathrm{agg}}=$ $360.7 \mathrm{~kJ} \cdot \mathrm{mol}^{-1}$ mentioned in the published paper was replaced by the correct $E_{A, \text { agg }}=271.2 \mathrm{~kJ} \cdot \mathrm{mol}^{-1}$.

(ii) In Figure 6, the caption "Pictures of the deposit collected on heat exchanger surface in the second and last channels of the PHE" has been replaced by "Pictures of the deposit collected on heat exchanger surface in the first and last channels of the PHE."
TABLE 3: Denaturation parameters at the two calcium concentrations.

\begin{tabular}{lcc}
\hline $\begin{array}{l}\text { Denaturation } \\
\text { parameter }\end{array}$ & $100 \mathrm{ppm}$ total calcium & $120 \mathrm{ppm}$ total calcium \\
\hline Unfolding & 124.8 & 117.2 \\
$\ln \left(k_{\text {unf }}^{\circ}\right)$ & 384.5 & 360.7 \\
$E_{A, \mathrm{unf}}\left(\mathrm{kJ} \cdot \mathrm{mol}^{-1}\right)$ & & \\
Aggregation & 86.3 & 83.1 \\
$\ln \left(k_{\mathrm{agg}}^{\circ}\right)$ & 271.2 & 260.4 \\
$E_{A, \text { agg }}\left(\mathrm{kJ} \cdot \mathrm{mol}^{-1}\right)$ &
\end{tabular}

Table 3 and Figure 6 are corrected here. 

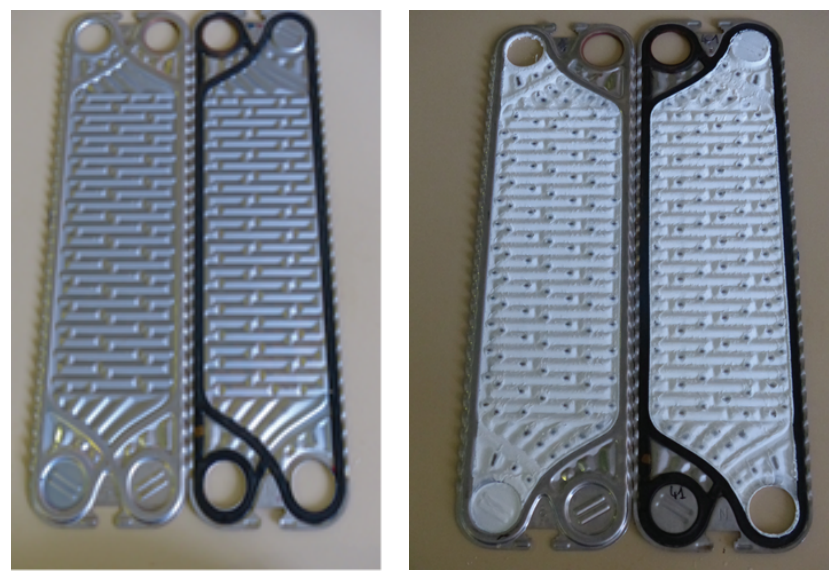

Figure 6: Pictures of the deposit collected on heat exchanger surface in the first and last channels of the PHE.

\section{References}

[1] M. Khaldi, G. Ronse, C. André et al., "Denaturation kinetics of whey protein isolate solutions and fouling mass distribution in a plate heat exchanger," International Journal of Chemical Engineering, vol. 2015, Article ID 139638, 10 pages, 2015. 


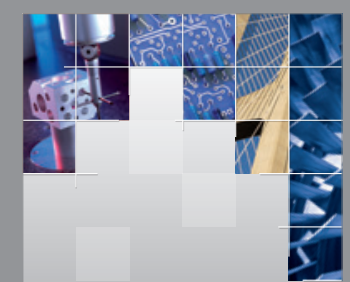

\section{Enfincering}
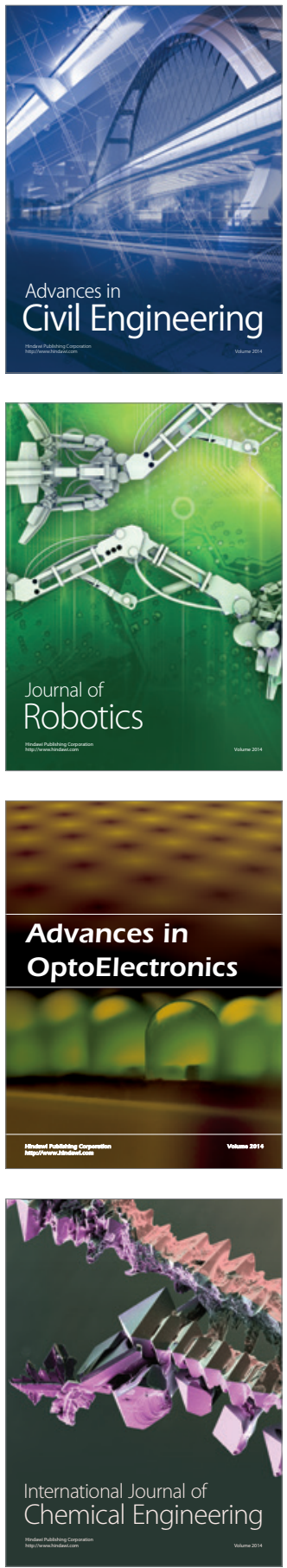

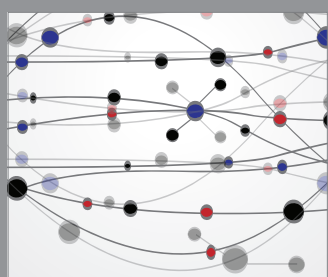

The Scientific World Journal

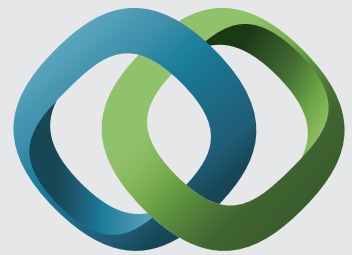

\section{Hindawi}

Submit your manuscripts at

http://www.hindawi.com
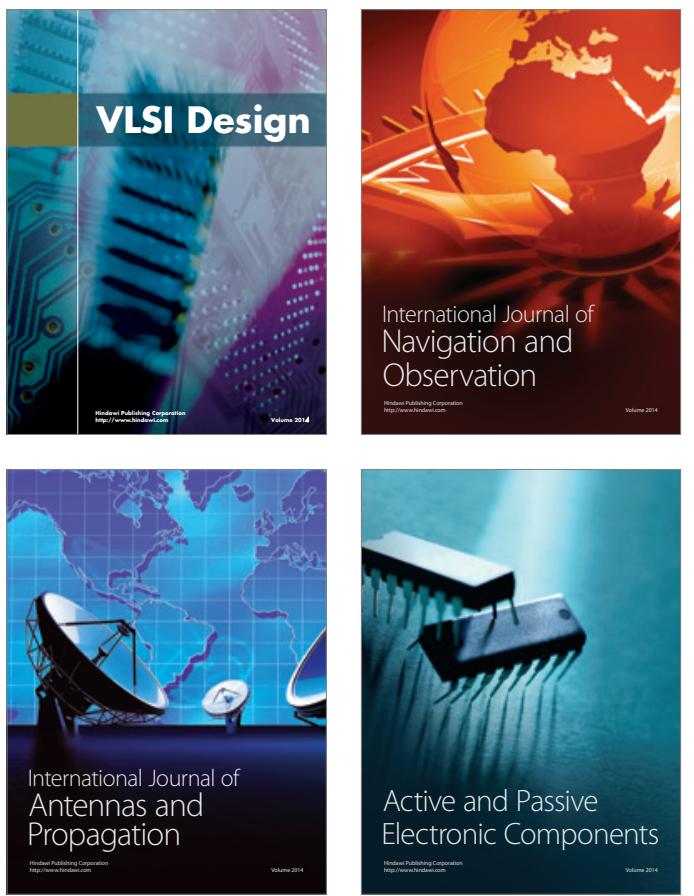
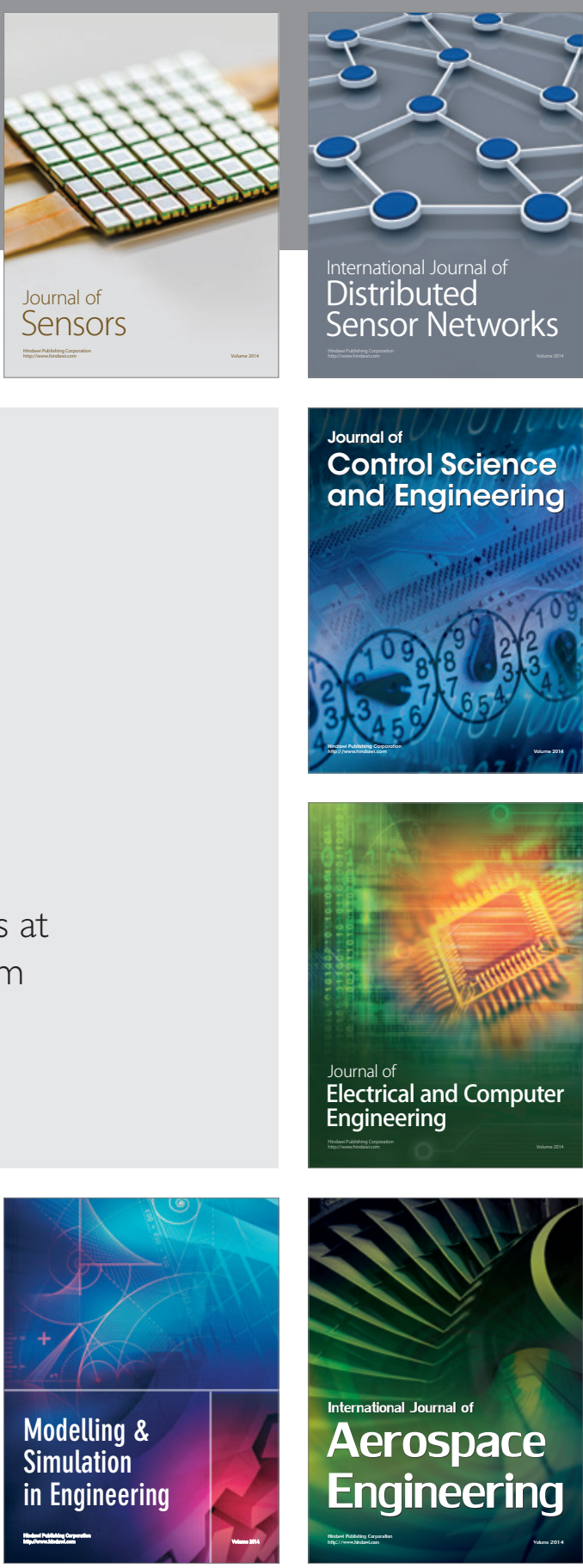

International Journal of

Distributed

Sensor Networks

Journal of

Control Science

and Engineering
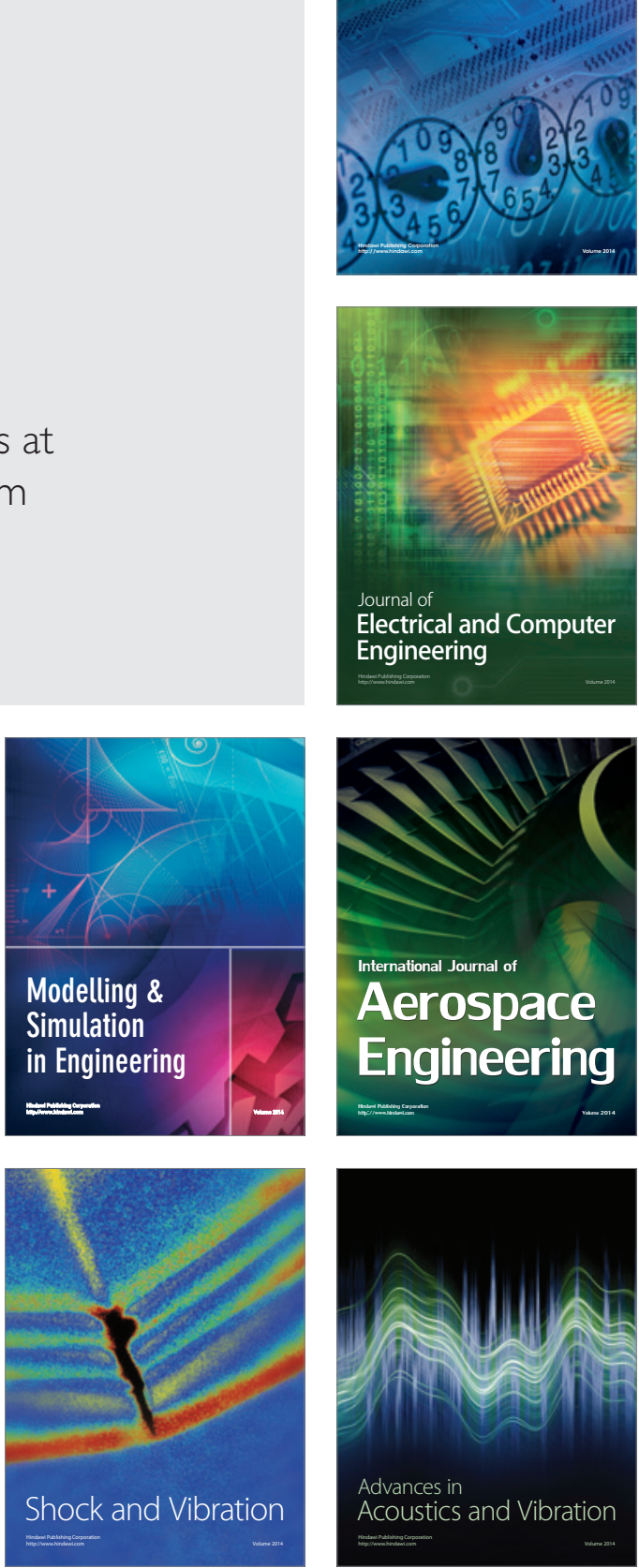